\title{
An RNA isolation system for plant tissues rich in secondary metabolites
}

\author{
Sanjay Ghawana ${ }^{1,2}$, Asosii Paul ${ }^{1}$, Hitesh Kumar ${ }^{1,3}$, Arun Kumar ${ }^{1}$, Harsharan Singh ${ }^{1,4}$, Pardeep K Bhardwaj ${ }^{1,5}$, \\ Arti Rani ${ }^{1,6}$, Ravi S Singh ${ }^{1}$, Jyoti Raizada ${ }^{1}$, Kashmir Singh ${ }^{1,7}$ and Sanjay Kumar ${ }^{1 *}$
}

\begin{abstract}
Background: Secondary metabolites are reported to interfere with the isolation of RNA particularly with the recipes that use guanidinium-based salt. Such interference was observed in isolation of RNA with medicinal plants rheum (Rheum australe) and arnebia (Arnebia euchroma). A rapid and less cumbersome system for isolation of RNA was essential to facilitate any study related to gene expression.
\end{abstract}

Findings: An RNA isolation system free of guanidinium salt was developed that successfully isolated RNA from rheum and arnebia. The method took about 45 min and was successfully evaluated on twenty one tissues with varied secondary metabolites. The $A_{260 / 280}$ ratio ranged between $1.8-2.0$ with distinct $28 \mathrm{~S}$ and $18 \mathrm{~S}$ rRNA bands visible on a formaldehyde-agarose gel.

Conclusions: The present manuscript describes a rapid protocol for isolation of RNA, which works well with all the tissues examined so far. The remarkable feature was the success in isolation of RNA with those tissues, wherein the most commonly used methods failed. Isolated RNA was amenable to downstream applications such as reverse transcription-polymerase chain reaction (RT-PCR), differential display (DD), suppression subtractive hybridization (SSH) library construction, and northern hybridization.

\section{Background}

Deciphering the underlying mechanisms of gene expression, signal transduction, gene regulation and transcriptome analysis requires a whole gamut of techniques such as northern hybridization, reverse transcriptionpolymerase chain reaction (RT-PCR), and construction of cDNA libraries. Substantially pure and un-degraded RNA is a fundamental requisite for all these techniques. A large number of protocols have been developed or extensively modified [1-7], and commercial kits are also available for isolation of RNA from plant tissues. Most of these methods, including kits, were found to be unsuitable for isolation of RNA from Litchi chinensis, Pinus taeda, Pseudotsuga menziesii, Picea glauca, Griffonia simplicifolia and Albizia procera [2-4,6]. Some of these tissues have phenolic compounds, which get oxidized to form quinones. Quinones bind to RNA and hinder RNA isolation and/or downstream applications

\footnotetext{
* Correspondence: sanjayplp1@gmail.com

'Biotechnology Division, Institute of Himalayan Bioresource Technology

(CSIR), Palampur-176 061, Himachal Pradesh, India Full list of author information is available at the end of the article
}

[8]. Secondary metabolites often co-precipitate with RNA and affect yield, quality [3] and interfere with downstream applications [9]. Specific protocols developed for such tissues are usually time consuming and also tissue specific [2-7].

Our research work involved cloning of relevant genes from medicinal plants, rheum (Rheum australe) and arnebia (Arnebia euchroma), which are rich in secondary metabolites anthraquinones and alkannins/shikonins, respectively. The prevalent methods namely TRIzol ${ }^{\circledR}$ (Invitrogen, USA), RNeasy ${ }^{\mathbb{B}}$ (Qiagen, Germany) and guanidinium salt based method [5] either failed to isolate RNA or yielded negligible quantity of RNA from these plants (Figure 1). Three methods we tried utilized a guanidinium-based salt as one of the constituents of the RNA isolation system $[1,5,10]$. A guanidinium-based salt is a strong protein denaturant and inhibitor of RNase. Therefore, it is an ingredient of choice in most of the RNA isolation systems. However several tissues, including those mentioned above were recalcitrant to RNA isolation, possibly due to the presence of guanidinium salts $[3,6,7]$. The presence of secondary metabolites has been attributed to
C Biomed Central 


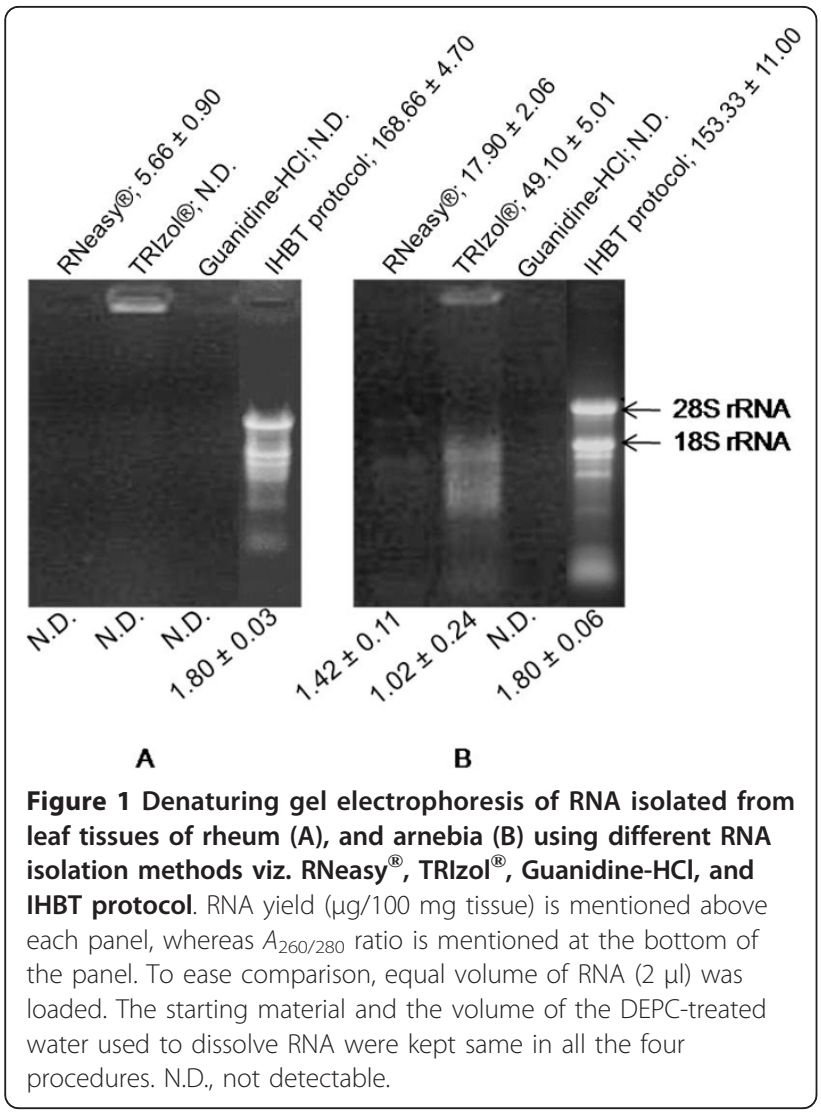

interfere with resuspension of RNA when extracted with guanidinium salts [3]. Since guanidinium salts are also ineffective in dissociating RNA from non-protein complexes, RNA may be lost along with the complex during isolation procedure $[11,12]$. It is also likely that the presence of guanidinium salt might promote such a complex formation that would further inhibit RNA isolation. Therefore, it was necessary to develop a composition which is free of guanidinium-based salt and at the same time the composition should possess protein-denaturant activity strong enough to inhibit RNase action.

Compositions free of guanidinium salt have been developed for isolation of RNA [3,6,7]. However, these procedures are time consuming, cumbersome, expensive and hence limit simultaneous processing of large number of samples. The present manuscript describes a protocol (IHBT protocol) for isolation of RNA from rheum and arnebia, which does not utilize guanidinium salt and also is simple and rapid. The developed protocol was extended to nineteen more plant tissues with success and the RNA isolated was amenable to downstream applications.

\section{Methods}

A total of 21 plant tissues were collected either from (i) the wild, (ii) cultivation in the experimental farm of the institute, or (iii) the local market.

\section{(a) Solutions and reagents}

- Water was always treated with $0.1 \%(\mathrm{v} / \mathrm{v})$ diethyl pyrocarbonate (DEPC) following standard procedure as detailed by Sambrook et al. [10].

- Solution I: phenol saturated with tris(hydroxymethyl) aminomethane buffer to a $\mathrm{pH}$ of $6.7 \pm 0.2$ was procured from Sigma, USA (catalogue number P4557). To this was added sodium dodecyl sulphate [SDS; 0.1\% (w/v)], sodium acetate $[\mathrm{NaOAc} ; 0.32 \mathrm{M}(\mathrm{w} / \mathrm{v})]$ and ethylenediaminetetra acetic acid (EDTA; $0.01 \mathrm{M}$ final concentration from a stock solution of $0.5 \mathrm{M}, \mathrm{pH} 8.0$ ).

- Chloroform

- 70\% Ethanol

- Isopropanol

\section{(b) Protocol for Isolation of RNA}

i. Grind 10-100 $\mathrm{mg}$ of tissue to a fine powder in liquid nitrogen using a mortar and pestle.

ii. Add $2 \mathrm{ml}$ of solution I, grind further. Solution I gets frozen as added; make fine powder of the frozen material; continue grinding so as to make a homogenous mixture; this ensures close contact of the tissue ingredients and the reagents that would help in instantaneous denaturation of protein. Allow to thaw completely with intermittent grinding.

iii. Add $800 \mu \mathrm{l}$ of DEPC-treated water, and mix it by grinding.

iv. Transfer the contents to two, $2 \mathrm{ml}$ micro-centrifuge tubes and leave for $5 \mathrm{~min}$ at room temperature. v. Add $200 \mu \mathrm{l}$ of chloroform to each tube, vortex briefly (< $10 \mathrm{~s}$ ) and leave for $10 \mathrm{~min}$ at room temperature.

vi. Centrifuge at $13,000 \mathrm{rpm}$ for $10 \mathrm{~min}$ at $4{ }^{\circ} \mathrm{C}$ and transfer the upper aqueous phase into fresh tubes.

vii. Add 0.6 volumes of isopropanol, vortex briefly (< $10 \mathrm{~s}$ ) and leave for $10 \mathrm{~min}$ at room temperature.

viii. Centrifuge at $13,000 \mathrm{rpm}$ for $10 \mathrm{~min}$ at $4{ }^{\circ} \mathrm{C}$ and discard the supernatant.

ix. Wash RNA pellet with $70 \%$ ethanol, air dry and dissolve in 20 to $50 \mu \mathrm{l}$ of DEPC-treated water.

Purity and concentration of RNA was assessed by determining the absorbance of the sample at 260 and $280 \mathrm{~nm}$ using a spectrophotometer (Specord 200, Analytica Jena, AG, Germany). Integrity of RNA was evaluated on a denaturing formaldehyde-agarose gel as described previously [13]. First strand cDNA was synthesized after digestion of RNA with RNase-free DNase I (amplification grade, Invitrogen, USA) and used for the amplification of $26 S r R N A$ [14]. Isolated RNA was also used for DD, northern analysis, SSH and rapid amplification of cDNA ends (RACE), and published elsewhere [13,15-17]. 


\section{Results and discussion}

A phenol-based, guanidinium salt-free protocol for isolation of RNA was developed. Reagents were selected based on their specific properties: phenol as a strong protein denaturant and inhibitor of RNase; SDS and EDTA are also inhibitors of RNase [18]. This composition provided a cocktail of RNase inhibitors and protein denaturant. Further, $\mathrm{pH}$ of the solution was maintained in the acidic range to allow efficient and preferable partitioning of RNA in the aqueous phase leaving DNA in the phenolic phase; DNA prefers basic $\mathrm{pH}$ for its partitioning into the aqueous phase [19]. An appropriate concentration of $\mathrm{NaOAc}$ was included in the solution to aid precipitation of RNA in the presence of isopropanol. The addition of DEPC-treated autoclaved water after addition of solution I rendered sufficient aqueous environment for partitioning of RNA into the aqueous phase. Our results suggested that the composition developed in the present communication had requisite protein denaturation and RNase inhibitory activity. It appears that the composition and the protocol provided an environment which prevented oxidation of phenolics leading to quick removal of these compounds from the extraction medium. This possibly allowed RNA to be free from quinone/protein complexes, and hence eased extraction and further re-suspension in water.

The developed method successfully isolated RNA from leaf tissues of rheum and arnebia with a yield of 168.66 \pm 4.7 and $153.33 \pm 11 \mu \mathrm{g}$ RNA/100 mg of tissue, respectively. This was remarkable in the light that other protocols either failed to yield RNA or yielded extremely low quantity (Figure 1). Though contamination of DNA can not be completely avoided, as is also reported with most of the rapid protocols [20,21], digestion of RNA with RNase-free DNase took care of the contamination (Figure 2). In fact, DNase digestion is a common step in protocols involving RNA analysis [13-15].

The method so developed was further extended to nineteen more tissues (Figure 3) from different plants having varying amount of secondary metabolites. The $A_{260 / 280}$ ratio of the isolated RNA ranged between 1.8 2.0, which indicated the RNA to be relatively free of proteins and contaminants. At times, low $A_{260 / 280}$ ratio ranging between 1.4 - 1.7 was also obtained, particularly when higher amount of the tissue was used. In all the cases, distinct $28 \mathrm{~S}$ and $18 \mathrm{~S}$ rRNA bands were observed on $1 \%$ formaldehyde-agarose denaturing gel indicating intact RNA. Also, the isolated RNA was amenable to downstream applications e.g. RT-PCR, DD, northern analysis, SSH and RACE, as reported in our publications that utilized the present protocol [13,15-17,22,23].

\section{Conclusion}

Unlike specific protocols for different tissues, the developed method was very useful in isolation of RNA not

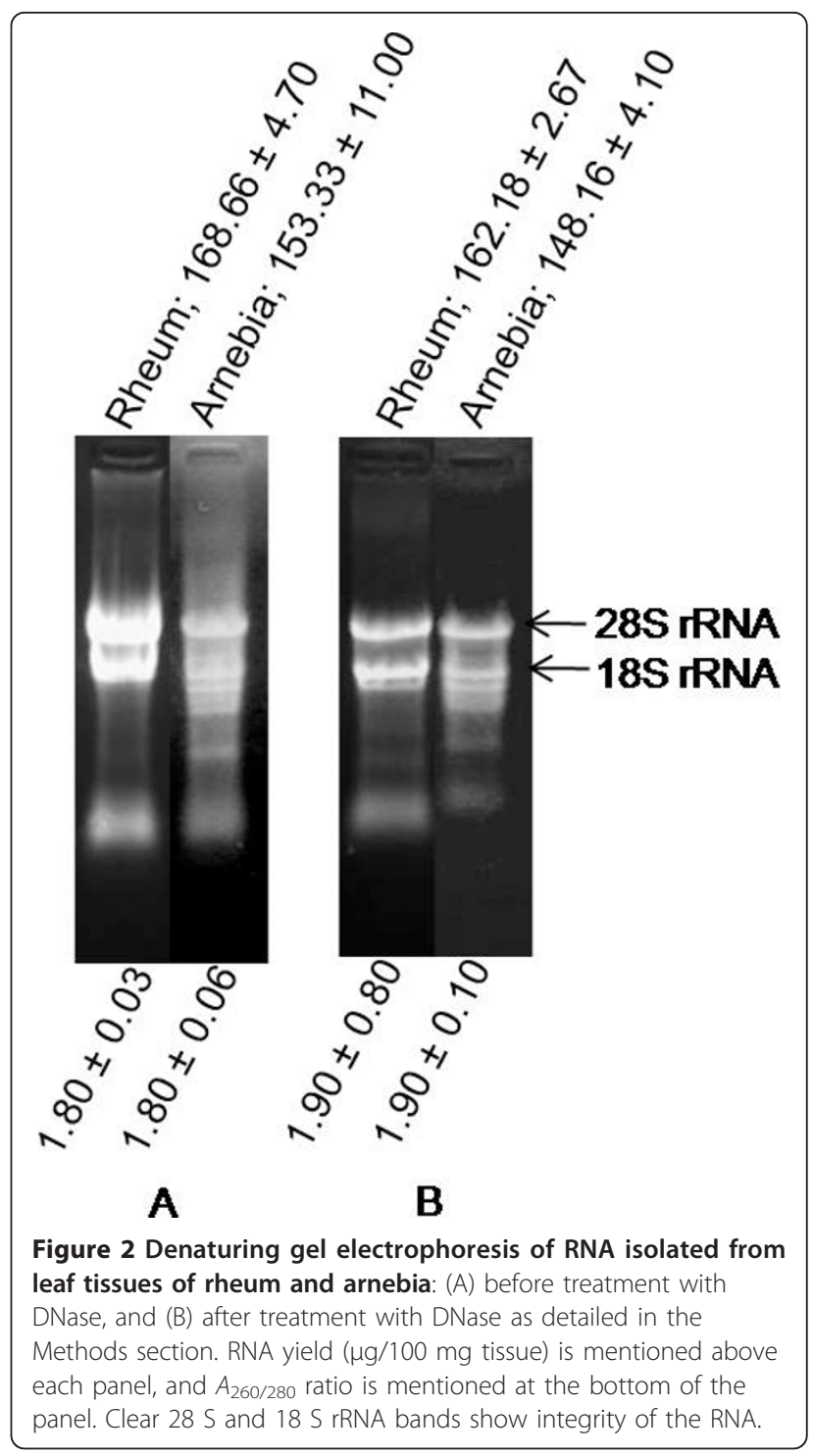

only from rheum and arnebia but also from various other plant species belonging to diverse genera. The distinguishing feature of the protocol was the success with those tissues wherein the commonly used protocols failed. The protocol is simple, does not require any specialized material, chemical, instrument and procedure such as ultracentrifugation step through cesium chloride gradient or lithium chloride precipitation, thereby greatly reducing the complications and the time required.

\section{Acknowledgements}

Authors thank Council of Scientific and Industrial Research (CSIR), India, for funding network projects CMM002 and CMM004 and to DBT, India for funding a project on bioprospection. SG, AP, AK, HS, PKB, AR, JR and KS acknowledge CSIR for Fellowship. HK gratefully acknowledges ICMR for Fellowship. RSS gratefully thanks UGC for Fellowship. Manuscript represents IHBT communication number 2061. The composition and protocol has been applied for patent vide number WO2007/113614A1. 


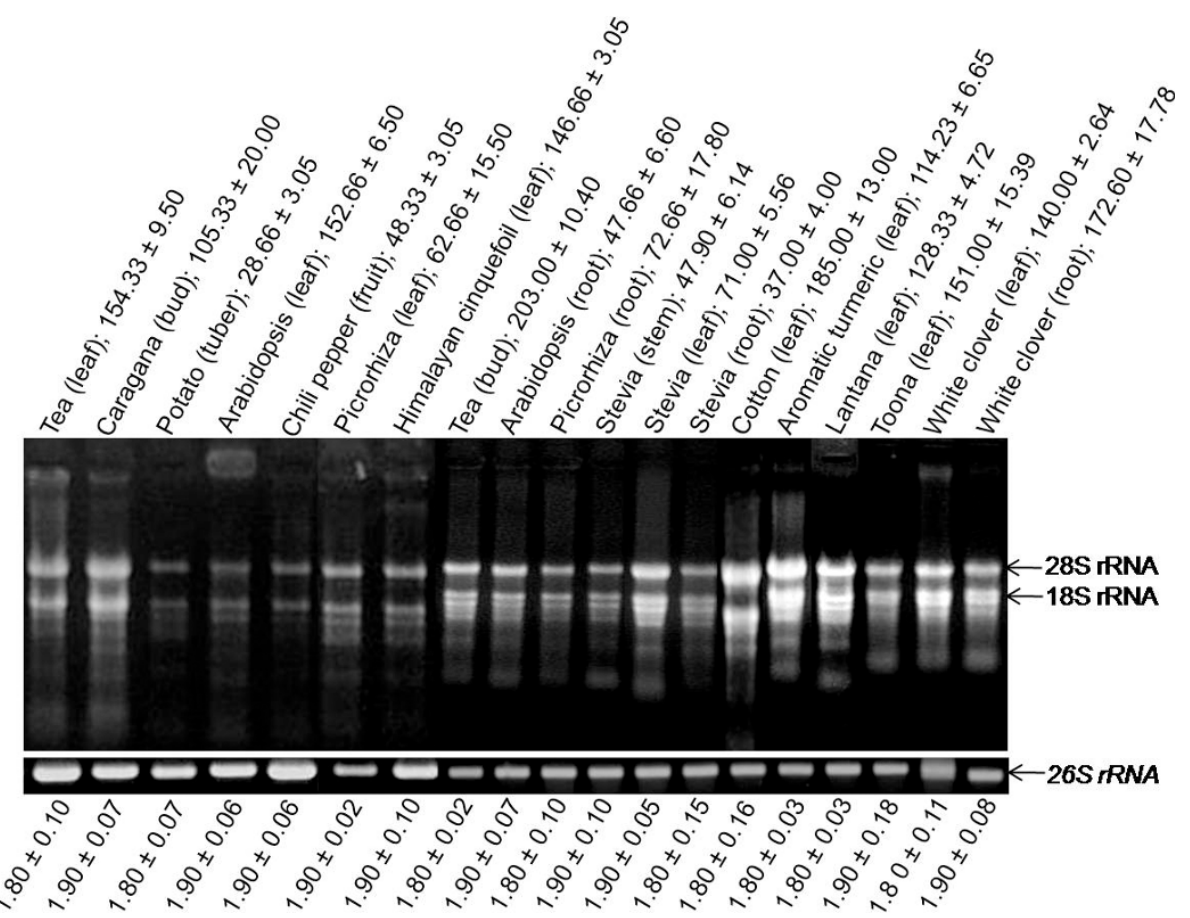

Figure 3 Denaturing gel electrophoresis of RNA isolated from different plant tissues using IHBT protocol. Name of plant tissues along with RNA yield ( $\mu \mathrm{g} / 100 \mathrm{mg}$ tissue) is written above each panel; $A_{260 / 280}$ ratio is mentioned at the bottom of the panel. The quality was assessed by electrophoresing an equal volume of RNA $(2 \mu \mathrm{l})$ on formaldehyde-agarose denaturing gel to observe integrity of $28 \mathrm{~S}$ and $18 \mathrm{~S}$ rRNA bands, and by confirming the amenability of isolated RNA to reverse transcription-polymerase chain reaction based amplification of $26 \mathrm{~S}$ rRNA. Tea (Camellia sinensis, Family: Theaceae), potato (Solanum tuberosum, Family: Solanaceae), chili pepper (Capsicum annum, Family: Solanaceae), picrorhiza (Picrorhiza kurrooa, Family: Scrophulariaceae), stevia (Stevia rebaudiana, Family: Asteraceae), aromatic turmeric (Curcuma aromatica, Family: Zingiberaceae), and lantana (Lantana camara, Family: Verbenaceae) is rich in flavanoids, polysaccharides, capsaicinoids, picrosides, steviosides, curcuminoids, and triterpenoids, respectively. Arabidopsis (Arabidopsis thaliana, Family: Brassicaceae) is a model plant, whereas the knowledge on the nature of secondary metabolites in caragana (Caragana jubata, Family: Fabaceae), Himalayan cinquefoil (Potentilla atrosanguinea, Family: Rosaceae), cotton (Gossypium hirsutum, Family: Malvaceae), toona (Toona sinensis, Family: Meliaceae), and white clover (Trifolium repens, Family: Fabaceae) was not available.

\section{Author details}

'Biotechnology Division, Institute of Himalayan Bioresource Technology (CSIR), Palampur-176 061, Himachal Pradesh, India. ²National Institute of Plant Genome Research, Aruna Asaf Ali Marg, P.O. Box No. 10531, New Delhi- 110 067, India. ${ }^{3}$ Assistant Professor, Department of Botany, SCVB Government College, Palampur-176 061, Himachal Pradesh, India. ${ }^{4}$ Assistant Professor, Biotechnology Division, Lyallpur Khalsa College, Jalandhar-144 001, Punjab, India. ${ }^{5}$ Scientist, Regional Centre of Institute of Bioresources and Sustainable Development (DBT), Tadong-737 102, Sikkim, India. ${ }^{6}$ Scientist, Vittal Mallya Scientific Research Foundation, \#94/3 \& 94/5, 23rd cross, 29th main, BTM II Stage, Bangalore-560 076, Karnataka, India. ${ }^{7}$ Assistant Professor, Department of Biotechnology, Panjab University, Chandigarh-160 014, India.

\section{Authors' contributions}

SG standardized various solutions and optimized protocol. AP, HK, AK, HS, PKB, AR, RSS, JR and KS carried out the experiments and participated in manuscript writing along with SG. SK guided on development of the RNA isolation system, guided the research and finally drafted the manuscript. All the authors have read the manuscript and agree with the content.

\section{Competing interests}

The authors declare that they have no competing interests.

Received: 1 January 2011 Accepted: 28 March 2011

Published: 28 March 2011

\section{References}

1. Chomczynski P, Sacchi N: Single-step method of RNA isolation by acid guanidinium thiocyanate-phenol-chloroform extraction. Anal Biochem 1987, 162:156-159.

2. Chang S, Puryear J, Cairney J: A simple and efficient method for isolating RNA from pine trees. Plant Mol Biol Rep 1993, 11:113-116.

3. Bugos RC, Chiang VL, Zhang XH, Campbell ER, Podila GK, Campbell WH: RNA isolation from plant tissues recalcitrant to extraction in guanidine. BioTechniques 1995, 19:734-737.

4. Salzman RA, Fujita T, Zhu-Salzman K, Hasegawa PM, Bressan RA: An improved RNA isolation method for plant tissues containing high levels of phenolic compounds or carbohydrates. Plant Mol Biol Rep 1999, 17:11-17.

5. Lal L, Sahoo R, Gupta RK, Sharma P, Kumar S: RNA isolation from highphenolic tea leaves and apical buds. Plant Mol Biol Rep 2001, 19:181a-181f.

6. Wang X, Tian W, Li Y: Development of an efficient protocol of RNA isolation from recalcitrant tree tissues. Mol Biotechnol 2008, 38:57-64

7. Ding LW, Sun QY, Wang ZY, Sun YB, Xu ZF: Using silica particles to isolate total RNA from plant tissues recalcitrant to extraction in guanidine thiocyanate. Anal Biochem 2008, 374:426-428.

8. Loomis WD: Overcoming problems of phenolic and quinones in the isolation of plant enzymes and organelles. Methods Enzymol 1974, 31:528-545.

9. Ghawana S, Singh K, Raizada J, Rani A, Bhardwaj P, Kumar S: A method for rapid isolation of RNA and a kit thereof. International Publication No. WO 2007/1136142007. 
10. Sambrook J, Fritsch EF, Maniatis T: Molecular Cloning: A Laboratory Manual. Cold Spring Harbor, Cold Spring Harbor Press; 1989.

11. Ghansal R, Raghuvanshi S, Sharma PC: Isolation of good quality RNA from a medicinal plant seabuckthorn rich in secondary metabolites. Plant Physiol Biochem 2009, 47:113-115.

12. Liu J-J, Goh C-J, Loh C-S, Liu P, Pua E-C: A method for isolation of total RNA from fruit tissues of banana. Plant Mol Biol Rep 1998, 16:1-6.

13. Bhardwaj PK, Ahuja PS, Kumar S: Characterization of gene expression of QM from Caragana jubata, a plant species that grows under extreme cold. Mol Biol Rep 2010, 37:1003-1010.

14. Singh K, Raizada J, Bhardwaj P, Ghawana S, Rani A, Singh H, Kaul K, Kumar S: 26 S rRNA-based internal control gene primer pair for reverse transcription-polymerase chain reaction-based quantitative expression studies in diverse plant species. Anal Biochem 2004, 335:330-333.

15. Ghawana S, Kumar S, Ahuja PS: Early low-temperature responsive mitogen activated protein kinases RaMPK1 and RaMPK2 from Rheum australe D. Don respond differentially to diverse stresses. Mol Biol Rep 2010, 37:933-938.

16. Kawoosa T, Singh H, Kumar A, Sharma SK, Devi K, Dutt S, Vats SK, Sharma M, Kumar S, Ahuja PS: Light and temperature regulated terpene biosynthesis: hepatoprotective monoterpene picroside accumulation in Picrorhiza kurrooa. Funct Integr Genomics 2010, 10:393-404.

17. Singh RS, Gara RK, Bhardwaj PK, Kaachra A, Malik S, Kumar R, Sharma M, Ahuja PS, Kumar S: Expression of 3-hydroxy-3-methylglutaryl-CoA reductase, $\mathrm{p}$-hydroxybenzoate-m-geranyltransferase and genes of phenylpropanoid pathway exhibits positive correlation with shikonins content in arnebia [Arnebia euchroma (Royle) Johnston]. BMC Mol Biol 2010, 11:88.

18. Dawson RMC, Elliott DC, Elliott WH, Jones KM: Data for Biochemical Research. Oxford Science Publication; 1986.

19. Wallace DM: Large and small-scale phenol extractions. Methods Enzymol $1987,152: 33-41$

20. Xu J, Aileni M, Abbagani S, Zhang P: A reliable and efficient Method for total RNA isolation from various members of Spurge family (Euphorbiaceae). Phytochem Anal 2010, 21:395-398.

21. Kiefer E, Heller W, Ernst D: A simple and efficient protocol for isolation of functional RNA from plant tissues rich in secondary metabolites. Plant Mol Biol Rep 2000, 18:33-39.

22. Rani A, Singh K, Sood P, Kumar S, Ahuja PS: $p$-Coumarate:CoA ligase as a key gene in the yield of catechins in tea [Camellia sinensis (L.) $\mathrm{O}$. Kuntze]. Funct Integr Genomics 2009, 9:271-275.

23. Singh K, Kumar S, Rani A, Gulati A, Ahuja PS: Phenylalanine ammonia-lyase (PAL) and cinnamate 4-hydroxylase (C4H) and catechins (flavan-3-ols) accumulation in tea. Funct Integr Genomics 2009, 9:125-134.

doi:10.1186/1756-0500-4-85

Cite this article as: Ghawana et al: An RNA isolation system for plant tissues rich in secondary metabolites. BMC Research Notes 2011 4:85.

\section{Submit your next manuscript to BioMed Central and take full advantage of:}

- Convenient online submission

- Thorough peer review

- No space constraints or color figure charges

- Immediate publication on acceptance

- Inclusion in PubMed, CAS, Scopus and Google Scholar

- Research which is freely available for redistribution 